\title{
Inhibition of temperature-dependent immobilization of fowl spermatozoa at body temperature by an increased intracellular $\mathrm{pH}$
}

\author{
K. Ashizawa ${ }^{\mathrm{I}}$, G. J. Wishart ${ }^{2}, \mathrm{H} . \mathrm{Nakao}^{\mathrm{I}}$, Y. Okino ${ }^{\mathrm{I}}$ and $\mathrm{Y}$. Tsuzuki $^{\mathrm{I}}$ \\ ${ }^{1}$ Laboratory of Animal Reproduction, Faculty of Agriculture, Miyazaki University, Miyazaki 889-21, \\ Japan; and ${ }^{2}$ Department of Molecular and Life Sciences, University of Abertay, Dundee DD1 1HG, UK
}

\begin{abstract}
Fowl sperm motility was measured by altering the extracellular $\mathrm{pH}\left(\mathrm{pH}_{\mathrm{e}}\right)$ at $30^{\circ} \mathrm{C}$ and $40^{\circ} \mathrm{C}$. At $30^{\circ} \mathrm{C}$, the motility of intact spermatozoa was vigorous in a medium in the wide $\mathrm{pH}_{\mathbf{e}}$ range of 7.3-10.1. In contrast, intact spermatozoa were almost immotile at $40^{\circ} \mathrm{C}$ in medium below a $\mathrm{pH}_{\mathrm{e}}$ of 8 .1. However, the motility could be restored by increasing the $\mathrm{pH}_{\mathrm{e}^{\prime}}$ maximum motility was obtained in medium at $\mathrm{pH}_{e}$ 9.4. Stimulation of the motility of demembranated spermatozoa at $40^{\circ} \mathrm{C}$ was also observed with an increased $\mathrm{pH}_{\mathrm{e}}$. However, demembranated spermatozoa at $40^{\circ} \mathrm{C}$ that had been stimulated by increasing the $\mathrm{pH}_{\mathrm{e}}$ lost their motility when $1 \mathrm{mmol} \mathrm{CaCl} \mathrm{l}^{-1}$ was added. Motility was restored by the subsequent

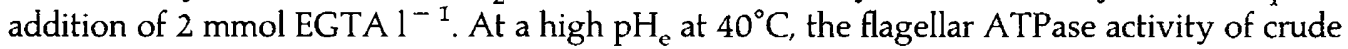
dynein extract was not affected, regardless of the addition of $\mathrm{CaCl}_{2}$ or EGTA. The intracellular $\mathrm{pH}\left(\mathrm{pH}_{\mathrm{i}}\right)$ of intact spermatozoa, estimated by measuring the accumulation of 9-aminoacridine fluorescence, increased with increasing $\mathrm{pH}_{e}$ at both $30^{\circ} \mathrm{C}$ and $40^{\circ} \mathrm{C}$. These results demonstrate that the reversible temperature-dependent immobilization of fowl spermatozoa at $40^{\circ} \mathrm{C}$ is inhibited by an increased $\mathrm{pH}_{\mathrm{i}}$. Furthermore, it is possible that the effects of the increased $\mathrm{pH}_{\mathrm{i}}$ may not act directly on dynein ATPase activity, but are mediated by a $\mathrm{Ca}^{2+}$-related substance(s) on the axoneme.
\end{abstract}

\section{Introduction}

There is evidence that intracellular $\mathrm{pH}\left(\mathrm{pH}_{\mathrm{i}}\right)$ is a potential trigger for the activation of sperm motility of many species of invertebrates and vertebrates (for reviews, see Brokaw, 1987; Lindemann and Kanous, 1989; Majumder et al., 1990; Morisawa and Morisawa, 1990). However, the detailed mechanisms of this phenomenon are unclear.

The activation of motility of sea urchin spermatozoa has been shown to depend on the presence of $\mathrm{Na}^{+}$in the medium, and is accompanied by a $\mathrm{Na}^{+}$-dependent release of $\mathrm{H}^{+}$from the cells (Nishioka and Cross, 1978) and by a rise of $\mathrm{pH}_{\mathrm{i}}$ (Christen et al., 1982; Lee et al., 1983). It is therefore proposed that the requirement of $\mathrm{Na}^{+}$for the initiation of motility is attributed to an increase in the $\mathrm{pH}_{\mathrm{i}}$ via the $\mathrm{Na}^{+}-\mathrm{H}^{+}$-ATPase in rat and sea urchin spermatozoa (Wong et al., 1981; Lee, 1984). Christen et al. (1983) showed that the intracellular alkalinization of sea urchin spermatozoa activates their respiration and induces a concomitant increase in the activity of dynein ATPase, suggesting that the dynein ATPase of the flagellar axoneme is the primary target for regulation by $\mathrm{pH}_{\mathrm{i}}$. Tombes and Shapiro (1985) postulated that energy for motility stimulated by an increased $\mathrm{pH}_{\mathrm{i}}$ is provided by mitochondrial respiration; energy transport from the sperm mitochondria to the tail involves distinct isozymes of creatine kinase that effect a phosphorylcreatine shuttle.

However, Morisawa and Morisawa (1988) demonstrated that rainbow trout spermatozoa and chum salmon spermatozoa

Received 9 November 1993. acquire the potential for motility as a result of an increase in the seminal plasma $\mathrm{pH}$ due to the increasing bicarbonate concentration during passage through the sperm duct. Under these conditions, an increase in extracellular $\mathrm{pH}\left(\mathrm{pH}_{\mathrm{e}}\right)$ causes the rise in intracellular cAMP (Morisawa et al., 1993). Similar results were obtained in bovine caput epididymal spermatozoa (Vijayaraghavan et al., 1985). It has been suggested that the dependence of sperm motility on $\mathrm{pH}_{\mathrm{i}}$ may play a significant role in maintaining the cAMP-dependent phosphorylated condition of the axoneme rather than directly activating dynein ATPase (Lindemann and Kanous, 1989), since the motility of demembranated bull spermatozoa without added cAMP is strongly dependent on alkaline $\mathrm{pH}(\mathrm{pH}>7.5)$, but with cAMP vigorous motility persists even at acidic $\mathrm{pH}$ (as low as $\mathrm{pH} 6.8$ ) (Goltz et al., 1988).

In contrast, Babcock et al. (1983) suggested that $\mathrm{pH}_{\mathrm{i}}$ plays a role in regulating the motility and metabolic activity of bovine cauda epididymal spermatozoa that is not mediated by cAMP, since cAMP-dependent protein kinase activity ratios in cellular extracts are increased by the addition of caffeine but not by alkaline $\mathrm{pH}$. Furthermore, Carr and Acott (1989) found at least four proteins from bovine epididymal spermatozoa that undergo changes in phosphorylation states in response to $\mathrm{pH}_{\mathrm{i}}$ modulation, but these authors suggested that the changes in phosphorylation are probably not due to changes in the concentration of cAMP, since they have previously shown that increasing $\mathrm{pH}_{\mathrm{i}}$ does not increase the amount of cAMP in bovine spermatozoa (Carr and Acott, 1984). 
Fowl spermatozoa provide an excellent system in which to examine the regulation of flagellar motility, as, unlike mammalian spermatozoa, fowl spermatozoa show reversible temperature-dependent changes in motility. In most synthetic diluents, they become immotile at the body temperature of $40-41^{\circ} \mathrm{C}$, but motility is restored by decreasing the temperature (Munro, 1938; Ashizawa and Nishiyama, 1978; Ashizawa and Okauchi, 1984; Ashizawa and Wishart, 1987, 1992; Wishart and Ashizawa, 1987; Thomson and Wishart, 1989, 1991). The axoneme itself appears to be directly involved in this regulatory system, since the motility of demembranated fowl spermatozoa is, as with intact spermatozoa, negligible at $40^{\circ} \mathrm{C}$ and restored at $30^{\circ} \mathrm{C}$ (Ashizawa et al., 1989a, b). However, the intracellular molecular cascade involved in immobilization and restoration of motility is unknown.

If changes in $\mathrm{pH}_{\mathrm{i}}$ are involved in the above temperaturedependent regulatory system, fowl spermatozoa might be expected to become motile even at $40^{\circ} \mathrm{C}$ after an increase in $\mathrm{pH}_{\mathrm{i}}$. However, little information is available about the effects of $\mathrm{pH}$ on the motility of fowl spermatozoa (Terada et al., 1981). In this study attempts were made to manipulate $\mathrm{pH}_{\mathrm{i}}$ by changing $\mathrm{pH}_{\mathrm{e}}$ and the effects of increasing $\mathrm{pH}_{\mathrm{i}}$ on the flagellar motility, metabolic activity and dynein ATPase activity of fowl spermatozoa were investigated at $30^{\circ} \mathrm{C}$ and $40^{\circ} \mathrm{C}$.

\section{Materials and Methods}

\section{Animals and preparation of spermatozoa}

Commercial White Leghorn roosters (Babcock strain, Akagi Poultry Breeding Farm, Miyazaki) were used throughout the study. All birds were housed in individual cages and fed ad libitum on a commercial breeder diet. They were exposed to a photoperiod of $14 \mathrm{~h}$ light: $10 \mathrm{~h}$ dark.

Semen was collected by the method of Bogdonoff and Shaffner (1954). Pooled semen was divided into seven aliquots and diluted by a factor of approximately ten in seven different buffers: $150 \mathrm{mmol} \mathrm{NaCl} \mathrm{l}^{-1}$ with $20 \mathrm{mmol} N$-tris[hydroxymethyl]-methyl-2-aminoethanesulfonic acid (TES) $1^{-1}$ adjusted to $\mathrm{pH} 7.5,8.0$ and 8.5 at $20^{\circ} \mathrm{C}$, or $150 \mathrm{mmol} \mathrm{NaCl}$ $1^{-1}$ with $20 \mathrm{mmol}$ 3-[cyclohexylamino]-2-hydroxy-1propanesulfonic acid (CAPSO) $\mathrm{I}^{-1}$ adjusted to $\mathrm{pH}$ 9.0, 9.5, 10.0 and 10.5 at $20^{\circ} \mathrm{C}$. The samples were centrifuged at $700 \mathrm{~g}$ for $13 \mathrm{~min}$ at room temperature $\left(20-25^{\circ} \mathrm{C}\right)$, and the washed spermatozoa were reconstituted in the same buffer to give a final concentration of approximately $1 \times 10^{9}$ cells ml $^{-1}$.

\section{Chemicals}

ATP, CAMP, 9-aminoacridine, BSA, CAPSO, desiccated firefly tails, dibutyryl-cAMP, dithiothreitol, potassium glutamate, TES and Triton X-100 were purchased from Sigma Chemical Co., St Louis, MO. Other chemicals were of reagent grade from Nacalai Tesque, Inc., Kyoto.

\section{Measurement of $\mathrm{pH}_{i}$ of intact spermatozoa at different $\mathrm{pH}_{e}$ values}

The $\mathrm{pH}_{\mathrm{i}}$ of spermatozoa was estimated by the method of Christen et al. (1982). Changes in fluorescence intensity induced by the addition of $150 \mu \mathrm{l}$ of the sperm sample to $2.85 \mathrm{ml}$ of the $\mathrm{NaCl}-\mathrm{TES}$ or NaCl-CAPSO buffer containing $2.5 \mu \mathrm{mol}$ 9-aminoacridine $1^{-1}$ were monitored continuously in a fluorescence spectrophotometer (Shimadzu, Model RF-5000, Kyoto). The concentration of spermatozoa was approximately $0.5 \times 10^{8}$ cells $\mathrm{ml}^{-1}$. An excitation wavelength of $398 \mathrm{~nm}$ was used and emitted fluorescence was measured at $456 \mathrm{~nm}$. The temperature of the cuvette was maintained at $30^{\circ} \mathrm{C}$ or $40^{\circ} \mathrm{C}$ by a circulating water jacket, and the sperm suspension was mixed continuously with a magnetic stirring bar.

\section{Measurement of motility of intact and demembranated spermatozoa at different $\mathrm{pH}_{e}$ values}

Sperm samples were preincubated aerobically in a shaking water bath at $30^{\circ} \mathrm{C}$ or $40^{\circ} \mathrm{C}$ for $10 \mathrm{~min}$. Intact spermatozoa were then diluted by a factor of approximately 250 in the same buffers, and the percentage of motile spermatozoa was measured at $30^{\circ} \mathrm{C}$ or $40^{\circ} \mathrm{C}$. Dibutyryl cAMP, when incorporated, was present at a final concentration of $4 \mathrm{mmol}^{-1}$.

Demembranation and reactivation of spermatozoa were performed at $30^{\circ} \mathrm{C}$ and $40^{\circ} \mathrm{C}$ according to the method described by Ashizawa et al. (1989b). The extraction medium used consisted of $0.1 \%$ Triton X-100, $200 \mathrm{mmol}$ sucrose $\mathrm{l}^{-1}$, $25 \mathrm{mmol}$ potassium glutamate $\mathrm{1}^{-1}, 1 \mathrm{mmol} \mathrm{MgSO}_{4} \mathrm{l}^{-1}$, $1 \mathrm{mmol}$ dithiothreitol $\mathrm{l}^{-1}$ and $20 \mathrm{mmol}$ Tris- $\mathrm{HCl} \mathrm{l}^{-1}(\mathrm{pH} 7.5-$ 8.5 , adjusted at $20^{\circ} \mathrm{C}$ ) or $20 \mathrm{mmol} \mathrm{CAPSO}{ }^{-1}$ (pH 9.0-10.5, adjusted at $20^{\circ} \mathrm{C}$ ). The reactivation medium consisted of $0.5 \mathrm{mmol} \mathrm{ATP} \mathrm{l}^{-1}, 200 \mathrm{mmol}$ sucrose $\mathrm{I}^{-1}, 25 \mathrm{mmol}$ potassium glutamate $1^{-1}, 1.5 \mathrm{mmol} \mathrm{MgSO}_{4} 1^{-1}, 1 \mathrm{mmol}$ dithiothreitol $\mathrm{I}^{-1}$ and $20 \mathrm{mmol}$ Tris- $\mathrm{HCl}^{-1}\left(\mathrm{pH} 7.5-8.5\right.$, adjusted at $\left.20^{\circ} \mathrm{C}\right)$

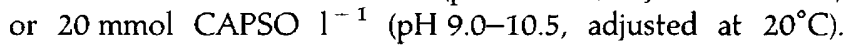
$\mathrm{CaCl}_{2}$, EGTA and cAMP, when incorporated, were present at final concentrations of $1 \mathrm{mmol} \mathrm{l}^{-1}, 2 \mathrm{mmol} 1^{-1}$ and $10 \mu \mathrm{mol}$ $\mathrm{I}^{-1}$, respectively.

The suspension of intact or demembranated spermatozoa was placed on a microscope chamber $(0.07 \mathrm{~mm}$ in depth, Sekisui Chemical Co., Ltd, Tokyo) and the motility of spermatozoa was recorded by videomicroscopy (magnification on the 12-inch black and white monitor was approximately $\times 600$ ) at $30^{\circ} \mathrm{C}$ or $40^{\circ} \mathrm{C}$ on a thermostatically controlled warm plate (Katz and Overstreet, 1981). The percentage of motile spermatozoa was determined by observing 200-300 spermatozoa, distributed uniformly among the three or more fields.

\section{Measurement of oxygen consumption and ATP concentrations of intact spermatozoa at different $\mathrm{pH}_{e}$ values}

Oxygen consumption of spermatozoa incubated in buffers of different $\mathrm{pH}$ was determined polarographically with a Clark electrode by the method of Kielley (1963), using a YSI biological oxygen monitor, model 53 (Yellow Springs Instrument Co., Inc., Yellow Springs, $\mathrm{OH}$ ). The rate of oxygen consumption was expressed in terms of $\mu \mathrm{I}_{2}$ consumed per $10^{8}$ spermatozoa $h^{-1}$. Numbers of spermatozoa were estimated by the method of Wishart and Ross (1985), using a double-beam spectrophotometer (Shimadzu, Model UV-150-02).

The concentration of ATP in spermatozoa incubated in buffers of different $\mathrm{pH}$ was assayed by firefly bioluminescence in a boiled extract (Wishart, 1982). 
Isolation of crude dynein extract and measurement of ATPase activity at different $\mathrm{pH}_{e}$ values

The method of McConnell et al. (1987) for the isolation of crude dynein from bovine spermatozoa was modified for use in fowl spermatozoa. Approximately $9 \times 10^{9}$ spermatozoa washed with $\mathrm{NaCl}-\mathrm{TES}$ buffer ( $\mathrm{pH}$ 7.4) were demembranated by resuspending the sperm pellet in $30 \mathrm{ml}$ of cold extraction medium, as described above ( $\mathrm{pH}$ 7.9). After centrifugation at $700 \mathrm{~g}$ for $10 \mathrm{~min}$ at $4^{\circ} \mathrm{C}$, demembranated spermatozoa were washed once with cold extraction medium excluding Triton X-100 and recentrifuged. Axonemal ATPase was solubilized by resuspending the demembranated spermatozoa in $0.6 \mathrm{~mol} \mathrm{NaCl}$ $1^{-1}, 20 \mathrm{mmol}$ Tris- $\mathrm{HCl} 1^{-1}(\mathrm{pH} 7.9), 1 \mathrm{mmol}$ dithiothreitol $\mathrm{l}^{-1}$ and $4 \mathrm{mmol} \mathrm{MgCl}_{2} 1^{-1}$ for $10 \mathrm{~min}$ at $4^{\circ} \mathrm{C}$. The supernatant obtained after centrifugation of the axonemal extract at $100000 \mathrm{~g}$ for $30 \mathrm{~min}$ at $4^{\circ} \mathrm{C}$ was designated as crude dynein extract.

ATPase activities were assayed by the reduction of ATP concentrations determined by firefly bioluminescence. The assay solution consisted of $20 \mathrm{mmol}$ Tris $-\mathrm{HCl}^{-1}$ ( $\mathrm{pH} 7.5-8.5$,

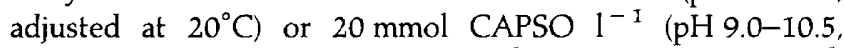
adjusted at $\left.20^{\circ} \mathrm{C}\right), 4 \mathrm{mmol} \mathrm{MgSO}_{4} \mathrm{I}^{-1}$ and $0.1 \mathrm{mmol} \mathrm{ATP} \mathrm{I}^{-1}$. $\mathrm{CaCl}_{2}$ and EGTA, when incorporated, were present at a final concentration of $1 \mathrm{mmol} \mathrm{l}^{-1}$ and $2 \mathrm{mmol} \mathrm{l}^{-1}$, respectively. The reaction was initiated by mixing $150 \mu \mathrm{l}$ of the assay solution and $15 \mu \mathrm{l}$ of crude dynein extract. After incubation for $30 \mathrm{~min}$ at $30^{\circ} \mathrm{C}$ or $40^{\circ} \mathrm{C}$, the reaction was stopped by boiling the mixture. The concentration of the remaining ATP was assayed by the method of Wishart (1982). Protein concentrations of crude dynein extract were determined using the method of Bradford (1976), with BSA as a standard. The rate of ATPase activity was expressed in terms of nmol ATP hydrolysis $\mathrm{mg}^{-1}$ protein min $^{-1}$.

\section{Statistical analysis} test.

Statistical comparisons were performed using Student's $t$

\section{Results}

Effects of $\mathrm{pH}_{e}$ on the $\mathrm{pH}_{i}$ of intact fowl spermatozoa

The $\mathrm{pH}_{\mathrm{i}}$ of intact spermatozoa, estimated by measuring the accumulation of 9-aminoacridine fluorescence, increased with increasing $\mathrm{pH}_{\mathrm{e}}$ at both $30^{\circ} \mathrm{C}$ and $40^{\circ} \mathrm{C}$. Regression equations were $y=0.42 x+4.58(r=0.94)$ at $30^{\circ} \mathrm{C}$ and $y=0.46 x+4.00$ $(r=0.93)$ at $40^{\circ} \mathrm{C}$. Both correlation coefficients were significant $(P<0.01)$; that is, at the same $\mathrm{pH}_{\mathrm{e}}$ value (about 7.0-8.5), acidification of $\mathrm{pH}_{\mathrm{i}}$ of spermatozoa by $0.25-0.30 \mathrm{pH}$ units was observed at $40^{\circ} \mathrm{C}$ compared with the $\mathrm{pH}_{\mathrm{i}}$ at $30^{\circ} \mathrm{C}$ (Fig. 1).

\section{Effects of $\mathrm{pH}_{e}$ on the motility of intact and demembranated fowl spermatozoa}

At $30^{\circ} \mathrm{C}$, the motility of intact spermatozoa was high in medium with the wide $\mathrm{pH}_{\mathrm{e}}$ range of $7.3-10.1$. In contrast, intact spermatozoa were almost immotile at $40^{\circ} \mathrm{C}$ in a medium

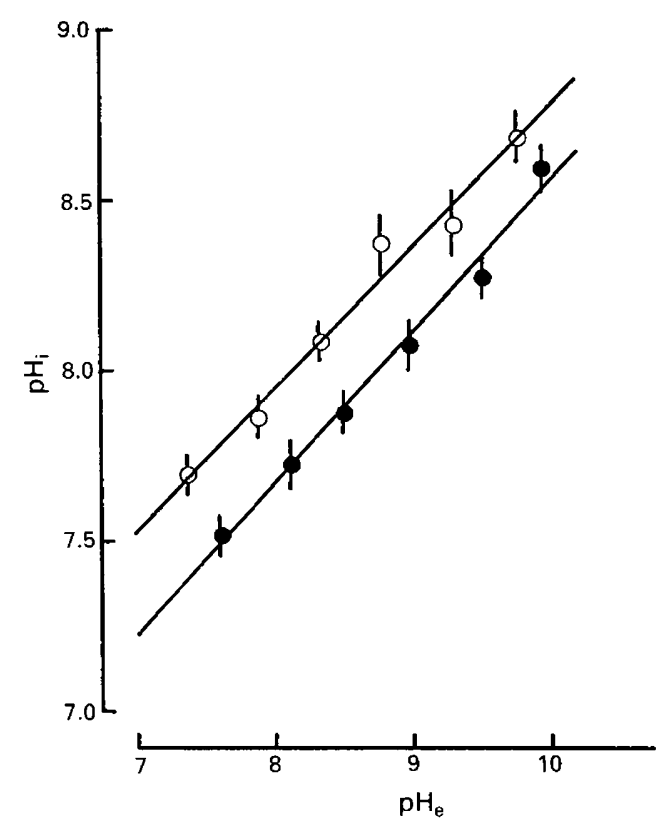

Fig. 1. The correlation between $\mathrm{pH}_{\mathrm{e}}$ and $\mathrm{pH}_{\mathrm{i}}$ of intact fowl spermatozoa at (O) $30^{\circ} \mathrm{C}$ and (-) $40^{\circ} \mathrm{C}$. Each point represents the mean ( \pm SEM) of five samples of spermatozoa.

below a $\mathrm{pH}_{e}$ of 8.I. However, the motility could be restored by increasing the $\mathrm{pH}_{\mathrm{e}}$. Maximum motility $(67 \%)$ was obtained in a medium at a $\mathrm{pH}_{\mathrm{e}}$ of 9.4 (Fig. 2a).

Stimulation of the motility of demembranated spermatozoa at $40^{\circ} \mathrm{C}$ was also observed if the $\mathrm{pH}_{\mathrm{e}}$ was increased (Fig. 2b). However, demembranated spermatozoa at $40^{\circ} \mathrm{C}$ that had been stimulated by increasing the $\mathrm{pH}_{\mathrm{e}}$ to 9.4 lost their motility when $1 \mathrm{mmol} \mathrm{CaCl} \mathrm{l}^{-1}$ was added. Motility was restored by the subsequent addition of 2 mmol EGTA $\mathrm{l}^{-1}$ (Fig. 3).

Furthermore, unlike mammalian spermatozoa (Goltz $e t$ al., 1988), the addition of $4 \mathrm{mmol}$ dibutyryl cAMP $\mathrm{I}^{-1}$ to intact spermatozoa or $10 \mu \mathrm{mol} \mathrm{cAMP} 1^{-1}$ to demembranated spermatozoa did not appreciably affect their motility in all the ranges of $\mathrm{pH}_{\mathrm{e}}$ examined, and similar values to those of control (no dibutyryl-cAMP or cAMP) were obtained at both $30^{\circ} \mathrm{C}$ and $40^{\circ} \mathrm{C}$ (Fig. $4 \mathrm{a}, \mathrm{b}$ ).

\section{Effects of $p H_{e}$ on the oxygen consumption, ATP concentrations and dynein ATPase activity of fowl spermatozoa}

Below a $\mathrm{pH}_{\mathrm{e}}$ of 9.4 , the rate of oxygen consumption at $30^{\circ} \mathrm{C}$ and $40^{\circ} \mathrm{C}$ showed almost constant values (Fig. $5 \mathrm{a}$ ).

The ATP concentrations at $30^{\circ} \mathrm{C}$ were fairly constant in the $\mathrm{pH}_{\mathrm{e}}$ range of 7.3-10.1. In contrast, an increased $\mathrm{pH}_{\mathrm{e}}$ at $40^{\circ} \mathrm{C}$ gradually decreased the ATP concentrations of spermatozoa (Fig. 5b).

The flagellar ATPase activity of crude dynein extract was stimulated by an increase in $\mathrm{pH}_{\mathrm{e}}$ at both $30^{\circ} \mathrm{C}$ and $40^{\circ} \mathrm{C}$, except at a $\mathrm{pH}_{\mathrm{e}}$ of 9.8 at $40^{\circ} \mathrm{C}$, although the activity at $40^{\circ} \mathrm{C}$ was higher than that at $30^{\circ} \mathrm{C}$ in all the ranges of $\mathrm{pH}_{\mathrm{e}}$ examined (Fig. 5c). Furthermore, at a high $\mathrm{pH}_{e}$ of 9.4 , this activity was not altered by the addition of $1 \mathrm{mmol} \mathrm{CaCl}{ }_{2} 1^{-1}(59.8 \pm 2.6 \mathrm{nmol}$ ATP hydrolysis $\mathrm{mg}^{-1}$ protein $\min ^{-1}$; mean \pm SEM of five 
(a)

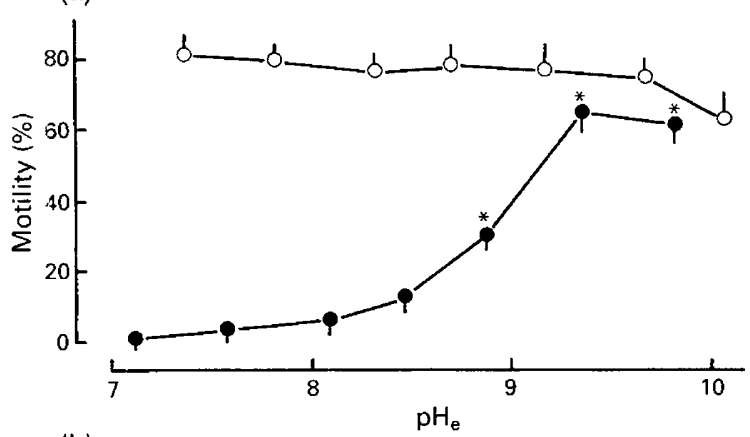

(b)

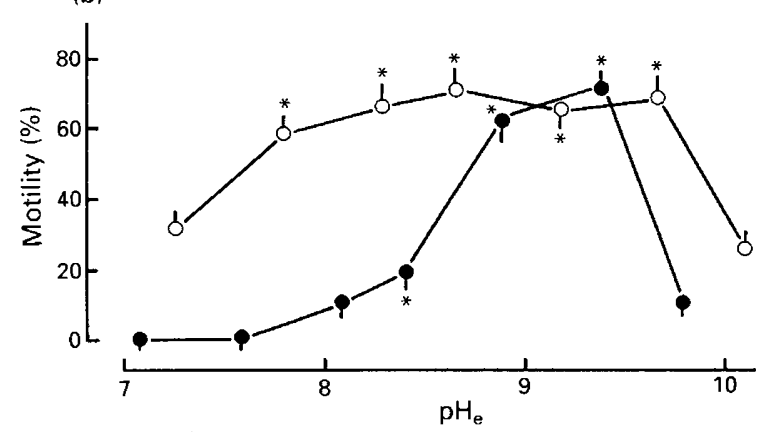

Fig. 2. Motility of (a) intact and (b) demembranated fowl spermatozoa at different $\mathrm{pH}_{\mathrm{e}}$ values at $(\mathrm{O}) 30^{\circ} \mathrm{C}$ and $(\bullet) 40^{\circ} \mathrm{C}$. Each point represents the mean ( \pm SEM) of five samples of spermatozoa. ${ }^{*} P<0.01$ compared with value at $\mathrm{pH}_{\mathrm{e}} 7.3$ at $30^{\circ} \mathrm{C}$ or $\mathrm{pH}_{\mathrm{e}} 7.1$ at $40^{\circ} \mathrm{C}$.

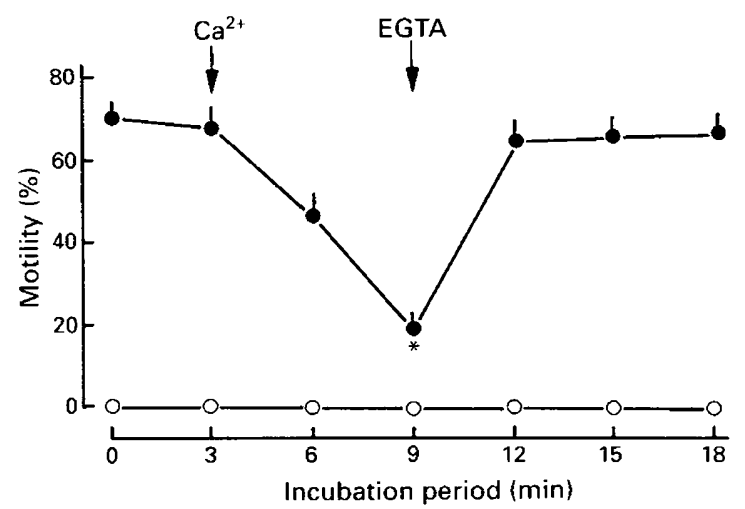

Fig. 3. Motility of demembranated fowl spermatozoa at $40^{\circ} \mathrm{C}$ at $(0)$ $\mathrm{pH}_{\mathrm{e}} 7.6$ and $(\bullet) \mathrm{pH}_{\mathrm{e}}$ 9.4. At arrows, $\mathrm{I} \mathrm{mmol} \mathrm{CaCl} \mathrm{l}^{-1}$ and $2 \mathrm{mmol}$ EGTA ${ }^{-1}$ were added. Each point represents the mean $( \pm \mathrm{SEM}$ ) of five samples of spermatozoa. ${ }^{*} P<0.01$ compared with value at 0 min.

samples) or by the addition of $1 \mathrm{mmol} \mathrm{CaCl} \mathrm{I}^{-1}$ followed by 2 mmol EGTA $1^{-1}(58.5 \pm 3.0)$ at $40^{\circ} \mathrm{C}$ compared with the activity when neither $\mathrm{CaCl}_{2}$ nor EGTA was added (59.7 \pm 3.2 ), even though the motility of demembranated spermatozoa was inhibited in the presence of $1 \mathrm{mmol} \mathrm{CaCl} \mathrm{I}^{-1}$ alone and was stimulated in the presence of $1 \mathrm{mmol} \mathrm{CaCl}{ }_{2} 1^{-1}$ plus $2 \mathrm{mmol}$ EGTA $~^{-1}$ at $40^{\circ} \mathrm{C}$ (Fig. 3).

\section{Discussion}

Gatti et al. (1991, 1993) demonstrated a linear relationship between $\mathrm{pH}_{\mathrm{i}}$ and $\mathrm{pH}_{\mathrm{e}}$ for ejaculated boar and ram spermatozoa.
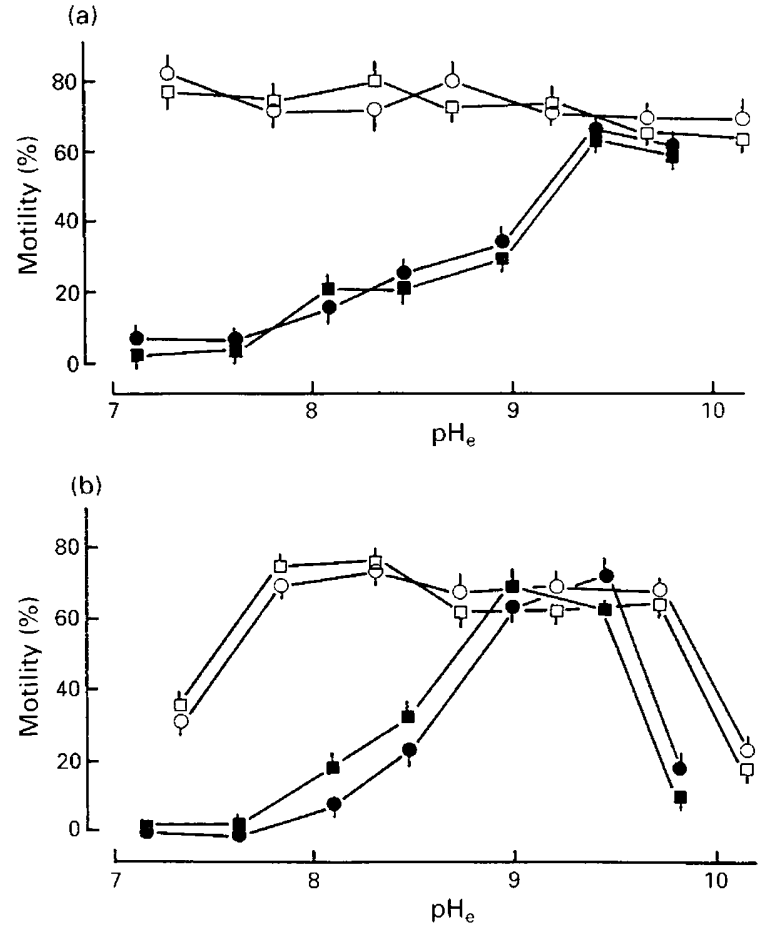

Fig. 4. Motility of (a) intact fowl spermatozoa at different $\mathrm{pH}_{e}$ values at $(\square, 0) 30^{\circ} \mathrm{C}$ and $(\mathbf{m}, \bullet) 40^{\circ} \mathrm{C}(\mathbf{\square}, \square)$ with or $(O, \bullet)$ without $4 \mathrm{mmol}$ dibutyryl-cAMP ${ }^{-1}$, and (b) demembranated fowl spermatozoa at different $\mathrm{pH}_{e}$ values at $(\square, 0) 30^{\circ} \mathrm{C}$ and $(\bullet, \bullet) 40^{\circ} \mathrm{C}(\square, \boldsymbol{\bullet})$ with or $(\circ, \bullet)$ without $10 \mu \mathrm{mol} \mathrm{CAMP} 1^{-1}$. Each point represents the mean ( \pm SEM) of five samples of spermatozoa. At both $30^{\circ} \mathrm{C}$ and $40^{\circ} \mathrm{C}$, no significant difference was observed between motility in the presence and absence of dibutyryl cAMP or cAMP at each $\mathrm{pH}_{\mathbf{e}}$.

In the present study, we also showed that the $\mathrm{pH}_{\mathrm{i}}$ of ejaculated fowl spermatozoa increases with increasing $\mathrm{pH}_{\mathrm{e}}$ at both $30^{\circ} \mathrm{C}$ and $40^{\circ} \mathrm{C}$. However, while the $\mathrm{pH}_{\mathrm{i}}$ changed by only approximately $1.3 \mathrm{pH}$ units, the $\mathrm{pH}_{\mathrm{e}}$ was changed by 3.0 units. Under these conditions, at the same $\mathrm{pH}_{e}$ value, the $\mathrm{pH}_{\mathrm{i}}$ at $40^{\circ} \mathrm{C}$ was $0.25-0.30$ units lower than that at $30^{\circ} \mathrm{C}$. This suggests that such an acidification might play some role in the temperaturedependent immobilization of fowl spermatozoa, since an increase in the $\mathrm{pH}_{\mathrm{i}}$ by 0.36 units upon dilution of sea urchin semen into seawater is sufficient to trigger the initiation of sperm motility (Johnson et al., 1983).

Our results also indicate that the temperature-dependent immobilization of intact fowl spermatozoa at $40^{\circ} \mathrm{C}$ was inhibited by a high $\mathrm{pH}_{\mathrm{e}}$, although the motility could be restored in a medium above $\mathrm{pH}_{e} 8.5$. However, the mechansim by which changes in $\mathrm{pH}$ stimulate sperm motility is not known. As the $\mathrm{pH}_{\mathrm{e}}$ is raised, a much larger stimulation of respiration of sea urchin spermatozoa occurs with a given amount of $\mathrm{H}^{+}$efflux (Repaske and Garbers, 1983). Both respiration and motility of sea urchin and bovine cauda epididymal spermatozoa increase, when the $\mathrm{pH}_{\mathrm{i}}$ is high (Christen et al., 1982; Babcock et al., 1983). However, in the present study, the rate of oxygen consumption at $40^{\circ} \mathrm{C}$ showed almost constant values below $\mathrm{pH}_{\mathrm{e}} 9.4$, in spite of motility being stimulated at this $\mathrm{pH}_{\mathrm{e}}$ value. Under these conditions, the concentration of ATP in spermatozoa gradually decreased with an increased $\mathrm{pH}_{\mathrm{e}^{\prime}}$ suggesting 

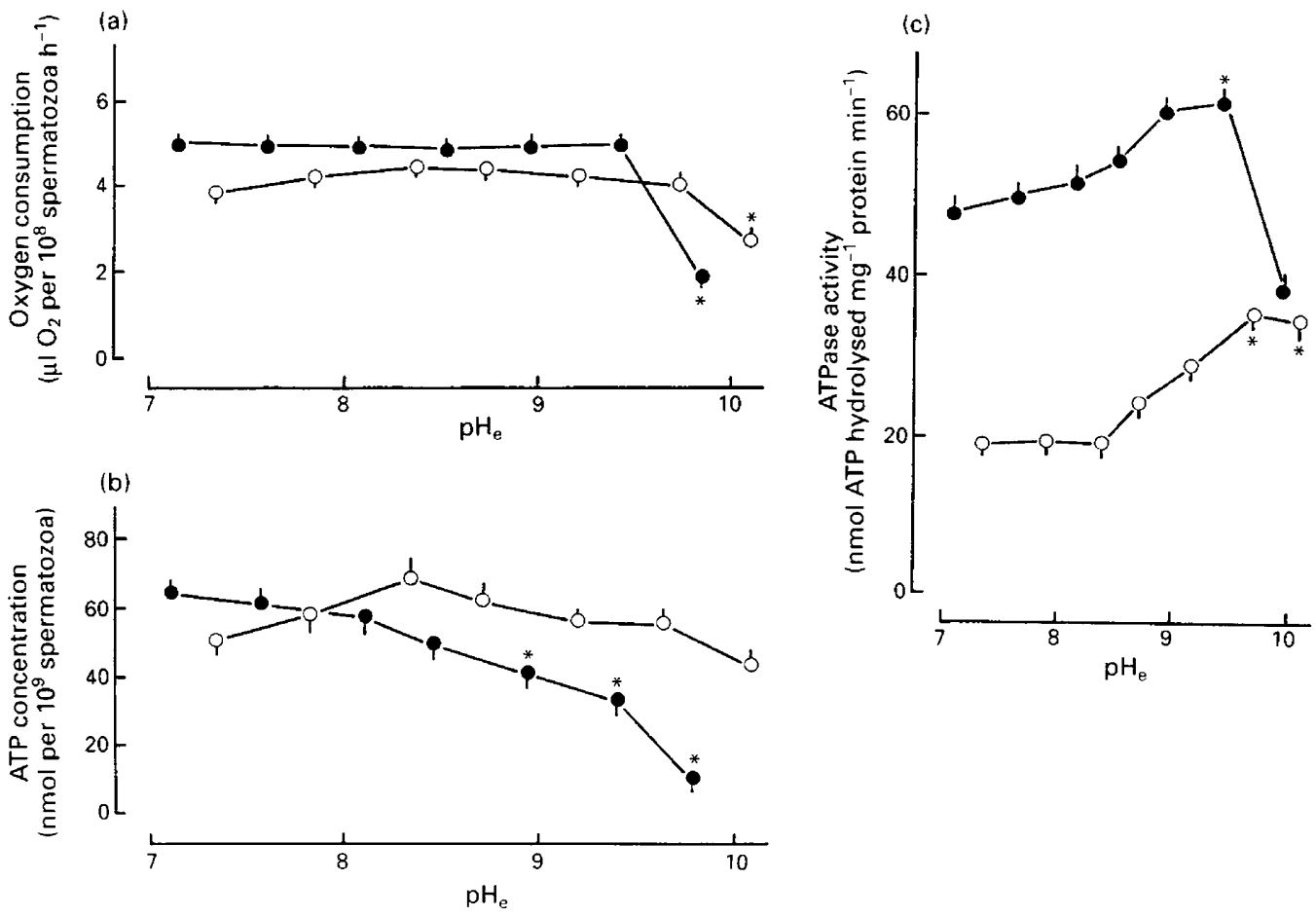

Fig. 5. (a) Oxygen consumption, (b) ATP concentration and (c) ATPase activity of crude dynein extract of fowl spermatozoa at different $\mathrm{pH}_{\mathrm{e}}$ values at $(0) 30^{\circ} \mathrm{C}$ and $(\bullet) 40^{\circ} \mathrm{C}$. Each point represents the mean ( \pm SEM) of five samples of spermatozoa. ${ }^{*} \mathrm{P}<0.01$ compared with value at $\mathrm{pH}_{\mathrm{e}} 7.3$ at $30^{\circ} \mathrm{C}$ or $\mathrm{pH}_{\mathrm{e}} 7.1$ at $40^{\circ} \mathrm{C}$.

that the concentration of ATP probably reflects coupling of ATP hydrolysis by the axoneme to the rate of respiration and oxidative phosphorylation.

Stimulation of the motility of demembranated fowl spermatozoa was also observed with an increased $\mathrm{pH}_{\mathrm{e}}$ that is, $\mathrm{pH}_{\mathrm{i}}$, suggesting that the effects of the increased $\mathrm{pH}_{\mathrm{i}}$ may act directly on the axoneme. If the $\mathrm{pH}_{\mathrm{i}}$ affects the axoneme directly, then the question of its locus of action is raised. The coupled activation of respiration and motility through an increased $\mathrm{pH}_{\mathrm{i}}$ seems to be due to the activation of dynein ATPase (Christen et al., 1983). We also showed that the flagellar ATPase activity of crude dynein extract was stimulated by an increased $\mathrm{pH}_{e}$ at both $30^{\circ} \mathrm{C}$ and $40^{\circ} \mathrm{C}$. Nevertheless, this rise in ATPase activity may not be a direct result of the inhibition of temperaturedependent immobilization of fowl spermatozoa at $40^{\circ} \mathrm{C}$, since the motility of both intact and demembranated fowl spermatozoa was almost negligible at $40^{\circ} \mathrm{C}$ between $\mathrm{pH}_{e}$ 7.1 and 8.1, even though the ATPase activity at $40^{\circ} \mathrm{C}$ was more than two times higher than that at $30^{\circ} \mathrm{C}$. Furthermore, the magnitude of dynein ATPase activity at $\mathrm{pH}_{\mathrm{e}}$ 9.4 did not decrease with the addition of $\mathrm{Ca}^{2+}$ at $40^{\circ} \mathrm{C}$, although the motility of demembranated spermatozoa was inhibited. These data suggest that the action of the increased $\mathrm{pH}_{\mathrm{i}}$ may not be directly on dynein ATPase activity, but may rather be mediated by other substance(s) on the axoneme.

Vijayaraghavan et al. (1985) provided evidence that a developmental increase in $\mathrm{pH}_{\mathrm{i}}$ in addition to a rise in the intracellular concentration of cAMP, is required for the expression of motility in bovine caput epididymal spermatozoa. Morisawa et al. (1993) proposed that the increases in seminal
$\mathrm{pH}$ affect membranous adenylate cyclase, which synthesizes cAMP, and this may be a factor inducing the acquisition of sperm motility in salmonid fishes. As similar results have been obtained in porcine spermatozoa (Tajima et al., 1987), it seems likely that intracellular cAMP is the primary target for regulation of sperm motility by $\mathrm{pH}_{\mathrm{i}}$ in these species. In fact, Goltz et al. (1988) demonstrated that the motility of demembranated bull spermatozoa without added cAMP is strongly dependent on alkaline $\mathrm{pH}(\mathrm{pH}>7.5)$, whereas in the presence of cAMP vigorous motility persists even at acidic $\mathrm{pH}$ (as low as $\mathrm{pH} 6.8$ ); this suggests that cAMP-dependent activation is crucial for motility at low $\mathrm{pH}\left(\mathrm{pH}\right.$ 6.4-7.1), which is the actual $\mathrm{pH}_{\mathrm{i}}$ of bull spermatozoa. In contrast, Babcock et al. (1983) suggested that cAMP may not be involved in initiating the motility of bovine cauda epididymal spermatozoa through an increase in $\mathrm{pH}_{\mathrm{i}}$, as no significant difference in CAMP-dependent protein kinase activity was observed between $\mathrm{pH} 6.8$ and 7.8 . The results presented here support Babcock's hypothesis, since the motility of both intact and demembranated fowl spermatozoa was not appreciably affected by dibutyryl cAMP or cAMP, and sperm motility was inhibited at low $\mathrm{pH}_{e}$ but activated at higher $\mathrm{pH}_{e}$ at $40^{\circ} \mathrm{C}$.

It should be noted that $\mathrm{Ca}^{2+}$ is indispensable for the maintenance of motility of demembranated fowl spermatozoa at $30^{\circ} \mathrm{C}$ (Ashizawa et al., 1992). In contrast, when the $\mathrm{pH}$ of reactivation medium is increased, the following observations were made: spermatozoa that had been stimulated by increasing the $\mathrm{pH}$ at $40^{\circ} \mathrm{C}$ lost their motility when $\mathrm{Immol} \mathrm{CaCl}_{2} \mathrm{I}^{-\mathrm{I}}$ was added. Motility was restored by the subsequent addition of $2 \mathrm{mmol}$ EGTA $^{-1}$. The reason for this is not well 
understood, but similar results were obtained by adding calyculin A or okadaic acid, specific inhibitors of protein serine-threonine phosphatases (K. Ashizawa, G. J. Wishart, H. Tomonaga, K. Nishinakama and $\mathrm{Y}$. Tsuzuki, unpublished). It is therefore possible that the increased $\mathrm{pH}_{\mathrm{i}}$ may act directly on axonemal phosphoprotein(s), mediated by a $\mathrm{Ca}^{2+}$-related substance(s). Carr and Acott (1989) found at least four proteins from bovine spermatozoa that have altered phosphorylation states in response to $\mathrm{pH}_{\mathrm{i}}$ modulations in a cAMP-independent manner. Additional studies are therefore necessary to examine whether such a phosphoroprotein(s) is involved in the stimulation of fowl sperm motility by an increasing $\mathrm{pH}_{\mathrm{i}}$.

This study was supported by a grant from the Ministry of Education, Science and Culture of Japan (No. 06660360).

\section{References}

Ashizawa K and Nishiyama H (1978) Effects of temperature on the vigour of motility, oxygen consumption and duration of motility of fowl spermatozoa under aerobic conditions Japanese Poultry Science 15, 264-266

Ashizawa K and Okauchi K (1984) Stimulation of sperm motility and oxygen consumption of fowl spermatozoa by a low molecular weight fraction of seminal plasma joumal of Reproduction and Fertility 71 593-598

Ashizawa K and Wishart GJ (1987) Resolution of the sperm motility-stimulating principle of fowl seminal plasma into $\mathrm{Ca}^{2+}$ and an unidentified low molecular weight factor Journal of Reproduction and Fertility $81495-499$

Ashizawa K and Wishart GJ (1992) Factors from fluid of the ovarian pocket that stimulate sperm motility in domestic hens Joumal of Reproduction and Fertility $95855-860$

Ashizawa K, Maeda S and Okauchi K (1989a) The mechanisms of reversible immobilization of fowl spermatozoa at body temperature Journal of Reproduction and Fertility 86 271-276

Ashizawa K, Suzuki Y and Okauchi K (1989b) Flagellar movement in demembranated preparations of ejaculated fowl spermatozoa Joumal of Reproduction and Fertility 86 263-270

Ashizawa K, Hashiguchi A and Tsuzuki Y (1992) Intracellular free $\mathrm{Ca}^{2+}$ concentration in fowl spermatozoa and its relationship with motility and respiration in spermatozoa Journal of Reproduction and Fertility 96 395-405

Babcock DF, Rufo GA, Jr and Lardy HA (1983) Potassium-dependent increases in cytosolic $\mathrm{pH}$ stimulate metabolism and motility of mammalian sperm Proceedings of the National Academy of Sciences, USA 80 1327-1331

Bogdonoff PD, Jr and Shaffner CS (1954) The effect of $\mathrm{pH}$ on in vitro survival, metabolic activity, and fertilizing capacity of chicken semen Poultry Science $33665-669$

Bradford MM (1976) A rapid and sensitive method for the quantitation of microgram quantities of protein utilizing the principle of protein-dye binding Analytical Biochemistry 72 248-254

Brokaw CJ (1987) Regulation of sperm flagellar motility by calcium and cAMP-dependent phosphorylation Journal of Cellular Biochemistry 35 175184

Carr DW and Acott TS (1984) Inhibition of bovine spermatozoa by caudal epididymal fluid: I. Studies of a sperm motilify quiescence factor Biology of Reproduction 30 913-925

Carr DW and Acott TS (1989) Intracellular pH regulates bovine sperm motility and protein phosphorylation Biology of Reproduction $41907-920$

Christen R, Schackmann RW and Shapiro BM (1982) Elevation of the intracellular $\mathrm{pH}$ activates respiration and motility of sperm of the sea urchin, Strongylocentrotus purpuratus Journal of Biological Chemistry 257 1488114890

Christen R, Schackmann RW and Shapiro BM (1983) Metabolism of sea urchin sperm: interrelationships between intracellular $\mathrm{pH}$, ATPase activity, and mitochondrial respiration journal of Biological Chemistry 258 5392-5399

Gatti JL, Chevrier C, Paquignon M, Dacheux JL and Christen R (1991) Relation between internal $\mathrm{pH}\left(\mathrm{pH}_{\mathrm{i}}\right)$ and motility of ram and boar spermatozoa Comparative Spermatology 75 369-371

Gatti JL, Chevrier C, Paquignon M and Dacheux JL (1993) External ionic conditions, internal $\mathrm{pH}$ and motility of ram and boar spermatozoa journal of Reproduction and Fertility 98 439-449
Goltz JS, Gardner TK, Kanous KS and Lindemann CB (1988) The interaction of $\mathrm{pH}$ and cyclic adenosine $3^{\prime}, 5^{\prime}$-monophosphate on activation of motility in Triton X-100 extracted bull sperm Biology of Reproduction 39 1129-1136

Johnson CH, Clapper DL, Winkler MM, Lee HC and Epel D (1983) A volatile inhibitor immobilizes sea urchin sperm in semen by depressing the intracellular $\mathrm{pH}$ Developmental Biology 98 493-501

Katz DF and Overstreet JW (1981) Sperm motility assessment by videomicrography Fertility and Sterility $35188-193$

Kielley WW (1963) Preparation and assay of phosphorylating submitochondrial particles: sonicated mitochondria Methods in Enzymology 6 272-277

Lee HC (1984) Sodium and proton transport in flagella isolated from sea urchin spermatozoa Journal of Biological Chemistry 259 4957-4963

Lee HC, Johnson C and Epel D (1983) Changes in internal pH associated with initiation of motility and acrosome reaction of sea urchin sperm Developmental Biology 95 3I-45

Lindemann CB and Kanous KS (1989) Regulation of mammalian sperm motility Archives of Andrology 23 1-22

McConnell JD, Stone DK, Johnson L and Wilson JD (1987) Partial purification and characterization of dynein adenosine triphosphatase from bovine sperm Biology of Reproduction 37 385-393

Majumder GC, Dey CS, Haldar S and Barua M (1990) Biochemical parameters of initiation and regulation of sperm motility Archives of Andrology 24 287-303

Morisawa S and Morisawa M (1988) Induction of potential for sperm motility by bicarbonate and $\mathrm{pH}$ in rainbow trout and chum salmon Joumal of Experimental Biology 136 13-22

Morisawa M and Morisawa S (1990) Acquisition and initiation of sperm motility. In Controls of Sperm Motility: Biological and Clinical Aspects pp 137-151 Ed. C Gagnon. CRC Press, Boca Raton

Morisawa S, Ishida K, Okuno M and Morisawa M (1993) Roles of $\mathrm{pH}$ and cyclic adenosine monophosphate in the acquisition of potential for sperm motility during migration from the sea to the river in chum salmon Molecular Reproduction and Development 34 420-426

Munro SS (1938) Fowl sperm immobilization by a temperature-media interaction and its biological significance Quarterly Joumal of Experimental Physiology 27 281-287

Nishioka D and Cross N (1978) The role of external sodium in sea urchin fertilization. In Cell Reproduction pp 403-413 Eds ER Dirksen, DM Prescott and CF Fox. Academic Press, New York

Repaske DR and Garbers DL (1983) A hydrogen ion flux mediates stimulation of respiratory activity by speract in sea urchin spermatozoa Journal of Biological Chemistry $2586025-6029$

Tajima Y, Okamura N and Sugita $Y$ (1987) The activating effects of bicarbonate on sperm motility and respiration at ejaculation Biochimica et Biophysica Acta 924 519-529

Terada T, Ashizawa K and Watanabe $\mathrm{M}$ (1981) Effects of $\mathrm{pH}$ on the motility and metabolism of cock spermatozoa Japanese Poultry Science 18 40-44

Thomson MF and Wishart GJ (1989) Elucidation of the mechanism responsible for the temperature-dependent reversible inactivation of the motility of fowl spermatozoa British Poultry Science 30 687-692

Thomson MF and Wishart GJ (1991) Temperature-mediated regulation of calcium flux and motility in fowl spermatozoa Journal of Reproduction and Fertility 93 385-391

Tombes RM and Shapiro BM (1985) Metabolite channeling: a phosphorylcreatine shuttle to mediate high energy phosphate transport between sperm mitochondrion and tail Cell 41 325-334

Vijayaraghavan S, Critchlow LM and Hoskins DD (1985) Evidence for a role for cellular alkalinization in the cyclic adenosine $3^{\prime}, 5^{\prime}$-monophosphate-mediated initiation of motility in bovine caput spermatozoa Biology of Reproduction 32 489-500

Wishart GJ (1982) Maintenance of ATP concentrations in and of fertilizing ability of fowl and turkey spermatozoa in vitro Joumal of Reproduction and Fertility $66 \quad 457-462$

Wishart GJ and Ashizawa K (1987) Regulation of the motility of fowl spermatozoa by calcium and cAMP Journal of Reproduction and Fertility $\mathbf{8 0}$ $607-611$

Wishart GJ and Ross FH (1985) Characterization of a spectrophotometric technique for the estimation of fowl and turkey sperm motility Gamete Research 11 169-178

Wong PYD, Lee WM and Tsang AYF (1981) The effects of extracellular sodium on acid release and motility initiation in rat caudal epididymal spermatozoa in vitro Experimental Cell Research 131 97-104 